\title{
Toxicity and toxicokinetics of cadmium in Capitella sp. I: relative importance of water and sediment as routes of cadmium uptake
}

\author{
Henriette Selck $^{1,2, *}$, Valery E. Forbes ${ }^{1}$, Thomas L. Forbes ${ }^{2}$ \\ ${ }^{1}$ Department of Life Sciences and Chemistry, Roskilde University, PO Box 260, DK-4000 Roskilde, Denmark \\ ${ }^{2}$ Department of Marine Ecology, National Environmental Research Institute, PO Box 358, Frederiksborgvej 399, \\ DK-4000 Roskilde, Denmark
}

\begin{abstract}
The importance of dissolved versus sediment-bound cadmium as uptake routes for the deposit-feeding polychaete Capitella species I and the toxicity and toxicokinetics of cadmium from these exposure routes were investigated. Effects were reported as changes in worm growth rate, egestion rate and allometry. Radioactive cadmium $\left({ }^{109} \mathrm{Cd}\right)$ was used as a tracer to examine the uptake (5 d) and subsequent depuration ( $6 \mathrm{~d}$ ) of cadmium. Both effects and kinetics were investigated in systems with and without sediment. Individual Capitella sp. 1 were exposed to (1) dissolved (i.e. $<0.45 \mu \mathrm{m}$ ) cadmium (water-only treatment), (2) sediment-bound cadmium (sediment-bound only treatment), or (3) both dissolved and sediment-bound cadmium (porewater \& sediment treatment). The porewater concentration of dissolved cadmium in porewater \& sediment treatments was set approximately equal to the dissolved concentration in water-only treatments $\left(0,25,50 \mu \mathrm{g} \mathrm{Cd} \mathrm{l}^{-1}\right)$. Worms in water-only treatments showed negative growth rates, which decreased linearly from -5 to $-10 \% \mathrm{~d}^{-1}$ with increasing cadmium concentration. Cadmium had no detectable effect on egestion rate or growth in the presence of sediment in either sediment-bound only $\left(\mathrm{ca} 36 \% \mathrm{~d}^{-1}\right.$ ) or porewater \& sediment $\left(\mathrm{ca} 30 \% \mathrm{~d}^{-1}\right)$ treatments. Cadmium exposure had no detectable effect on the allometric exponent (i.e. area-length relation) in any of the treatments; however, worms in water-only treatments were relatively thinner than in the 2 treatments with sediment. Worms in porewater \& sediment treatments took up ca 50 -fold more cadmium (ca $195 \mathrm{ng} \mathrm{Cd} \mathrm{worm}{ }^{-1}$ ) than worms in water-only treatments ( $3.9 \mathrm{ng} \mathrm{Cd}$ worm $\left.{ }^{-1}\right)$ during $5 \mathrm{~d}$ of exposure. Sediment-bound cadmium was calculated to contribute $95 \%$ of the total amount taken up by feeding worms. Starving worms retained all of the cadmium during the subsequent depuration period

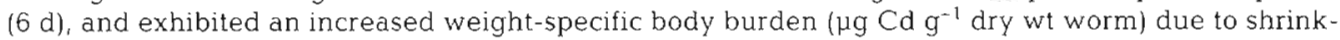
age. In feeding worms, the decrease in weight-specific body burden was faster $\left(T_{1 / 2}=3 \mathrm{~d}\right)$ than the decrease in total body burden ( $\mu \mathrm{g} \mathrm{Cd}$ worm ${ }^{-1}: \mathrm{Ti}_{1}=11 \mathrm{~d}$ ), indicating that both active excretion and dilution of cadmium body burden as a result of growth contributed to the change in cadmium tissue concentration during the depuration period. Thus, our results indicate that in Capitella sp. I sedimentbound cadmium is the major route of uptake. We found that cadmium affects starving but not fed worms, despite the fact that fed worms took up considerably more cadmium than starving worms. Our results suggest that stress associated with food limitation increases the susceptibility of worms to cadmium stress.
\end{abstract}

KEY WORDS: Bioavailability $\cdot$ Sediment quality criteria $\cdot$ Deposit feeder - Infauna

\section{INTRODUCTION}

Deriving biologically relevant exposure concentrations for sediment-associated contaminants remains a key challenge in the development of sediment quality

•E-mail: hse@virgil.ruc.dk criteria. Sediments can serve as both a sink and a source of anthropogenically derived contaminants, partly as a result of the influence of benthic fauna on sediment biogeochemistry and contaminant fate (e.g. Reynoldson 1987, Baudo \& Muntau 1990, Power \& Chapmann 1992, Campbell \& Tessier 1996). Since benthic fauna both influence and are influenced by contaminant fate in sediments, there is likely to be rather 
tight coupling between the geochemical fate and biological effects of sediment-associated contaminants (Rhoads 1974, Reynoldson 1987, Forbes \& Forbes 1994).

Like many anthropogenically derived metals, cadmium accumulates in aquatic sediments and reaches its highest concentrations mainly in coastal and estuarine areas (Theede 1980, Ankley et al. 1994, Campbell \& Tessier 1996). Benthic organisms are able to accumulate cadmium via overlying water, porewater and ingested particles, and the determination of the relative importance of these different routes of uptake and subsequent toxicity to bottom-dwelling organisms is critical for assessing the risks associated with contaminated sediments. Results to date on the relative importance of the different routes of uptake remain inconclusive. Experiments with the facultative deposit feeder Macoma balthica showed that dissolved cadmium was most important when the bivalve was suspension feeding (Harvey \& Luoma 1985a) and much less important when the bivalve deposit-fed on cadmium-contaminated sediment (Harvey \& Luoma 1985b). Much of the uptake of cadmium by the deposit-feeding bivalve Scrobicularia plana was attributed to ingestion of sediment (Bryan \& Uysal 1978). However, survival and reburial of the amphipod $R h e p-$ oxynius abronius was related to the amount of cadmium dissolved in the porewater rather than to the total cadmium concentration in bulk sediment (Kemp \& Swartz 1988). Bryan \& Hummerstone (1973) found that the polychaete Nereis diversicolor mainly absorbed cadmium from solution in the porewater, but uptake from food couid not be neglected. In Nereis virens, accumulation rates of cadmium from the bulk sediment (i.e. sediment plus porewater) were equal to the rates from seawater (water-only exposure), indicating that uptake in this species occurs primarily via the aqueous phase (Ray et al. 1980). The same was found for Nereis japonica (Ueda et al. 1976). Thus, the available results suggest that interspecific physiological and behavioral differences (e.g. feeding behavior, feeding rate and metal excretion) may be crucial in determining the relative importance of different routes of metal uptake.

The objectives of this study were to investigate the relative importance of dissolved (i.e. $<0.45 \mu \mathrm{m}$ ) versus sediment-bound cadmium as uptake routes and the toxicity and toxicokinetics of cadmium from these exposure routes to the deposit-feeding polychaete Capitella sp. I. Capitella species typically occur in depositional environments containing organically enriched sediments (Tsutsurai 1987, 1990, Tsutsumi et al. 1990, 1991, Forbes et al. 1994). The genus Capitella consists of numerous sibling species of which Capitella sp. I is the most opportunistic (Grassle \& Grassle 1974).
Capitella species live in tubes in the top few centimeters of the sediment, where they ventilate and feed (Grassle \& Grassle 1976). Capitella sp. I was chosen for the present study, because its feeding strategy includes processing large quantities of fine-grained sediment and because the environments containing organically enriched sediments, which are ideal habitats for this species, often are sites of high heavy metal contamination (Pearson \& Rosenberg 1978). Cadmium was chosen because it is characterized as one of the most toxic heavy metals (Theede 1980, Baudo \& Muntau 1990) and is known to have an important influence on the energetics of benthic invertebrates (e.g. Theede 1980, Forbes 1991, Forbes \& Depledge 1992).

Cadmium toxicity and toxicokinetics were investigated both in systems with and without sediment. Individual worms were exposed to (1) dissolved, (2) sediment-bound or (3) both dissolved and sedimentbound cadmium. ${ }^{109} \mathrm{Cd}$ was used as a tracer to investigate worm uptake and depuration, and the effects of cadmium were reported as changes in worm growth rate, egestion rate and allometry.

\section{MATERIALS AND METHODS}

General. Sediment for all experiments was collected from the Isefjord (station 63; Rasmussen 1973), Denmark, by scraping off and removing the top few centimeters of the sediment surface with a spatula. This station is located far from any sources of metal contamination and is routinely used for culturing worms. The sediment was sieved (to $<250 \mu \mathrm{m}$ ) and subsequently frozen $\left(-20^{\circ} \mathrm{C}\right)$ until use. Percent particulate organic matter was $3.32 \%( \pm 0.05 \%, n=4)$ as determined by loss on ignition $\left(6 \mathrm{~h}\right.$ at $\left.500^{\circ} \mathrm{C}\right)$. Sediment was blended before use to disrupt particle aggregates.

A laboratory culture of Capitella sp. I was reared in an aerated aquarium (10 l) at $13^{\circ} \mathrm{C}$ on sediment with regular additions of ground fish food (Tetra Min) as a supplementary food.

Preparation of contaminated sediments. Contaminated seawater was made by adding a known volume of cadmium stock solution $\left(\mathrm{CdCl}_{2}\right.$ dissolved in $\left.0.5 \mathrm{M} \mathrm{HCl}\right)$ to a known volume of filtered $(0.2 \mu \mathrm{m})$ seawater $(31 \%)$. Cadmium-contaminated sediments were made by pipetting a known volume of wet sediment $(<250 \mu \mathrm{m})$ into a known volume of the previously contaminated seawater. Cadmium was allowed to equilibrate among overlying water, porewater and sediment for $24 \mathrm{~h}$ after addition of sediment. Preliminary studies showed that cadmium concentration in each compartment attained a constant concentration within this time scale. Sediments were prepared at 4 cadmium concentrations and controls (i.e. without $\mathrm{Cd}$ addition) (see below). All of the Cd treat- 
ments were within the range of concentrations occurring in polluted sediments (Bryan 1984). Radioactive cadmium was used to trace cadmium administered via different exposure routes and to determine the amount of cadmium taken up or depurated by Capitella sp. I. Radioactively labeled seawater and sediments were made by adding a small amount of radioactive cadmium $\left({ }^{109} \mathrm{CdCl}_{2}\right.$ in $\left.0.5 \mathrm{M} \mathrm{HCl}\right)$ to the contaminated seawater prior to addition of wet sediment.

Experimental treatments. Three different groups of treatments were used, namely 'water-only' (WO), 'sediment-bound only' (SBO) and 'porewater \& sediment' (PWS) (see Tables $1 \& 2$ ). WO worms were exposed to dissolved cadmium (i.e. free Cd ions and other Cd species in solution $;<0.45 \mu \mathrm{m}$ ) whereas $\mathrm{SBO}$ worms were exposed to sediment-bound cadmium only. The total amount of cadmium added to WO and SBO treatments was equal. Based on results of the preliminary studies, in which the porewater concentration in similar treatments was below detection, the porewater concentration in SBO was estimated as zero. PWS worms were exposed to both dissolved and sediment-bound cadmium. The dissolved porewater concentration of cadmium in PWS was set approximately equal to the concentration to which worms in WO were exposed.

Each treatment was subdivided into a control and 2 cadmium concentrations. Details of exposure conditions within treatments are given in Table 1. Experiments were maintained in light, and initial worm body volumes (BV) were between 0.9 and $1.3 \mathrm{~mm}^{3}$ in WO and PWS treatments and between 0.1 and $0.25 \mathrm{~mm}^{3}$ in SBO treatments. Only male worms were used, so as to minimize potential effects of reproductive condition (e.g. presence of lipid-rich eggs) on worm physiology and/or cadmium kinetics.

The nominal dissolved cadmium concentrations involved in WO and SBO (before sediment was added)

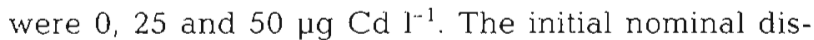
solved cadmium concentrations in PWS were 0, 4.1 and $8.2 \mathrm{mg} \mathrm{Cd} \mathrm{1}^{-3}$, which resulted in porewater concentrations of approximately 0,25 and $50 \mu \mathrm{g} \mathrm{Cd} \mathrm{l}^{-1}$, respectively (Table 1). Note that the consequence of setting the porewater concentration in PWS equal to the dissolved concentration in WO was that worms in PWS were exposed to a very large sediment-bound pool of cadmium. The relation between the total amount of cadmium added $\left([\mathrm{Cd}]_{\text {tolal }}\right)$ to PWS treatments and the subsequent equilibrium concentration in the porewater ([Cd $\left.]_{\text {porewater }}\right)$ was described by:

$$
\begin{gathered}
{[\mathrm{Cd}]_{\text {porewater }}=0.0055[\mathrm{Cd}]_{\text {total }}+3.99} \\
(\mathrm{r}=0.849, \mathrm{p}<0.001)
\end{gathered}
$$

and the concentration of cadmium in the sediment was estimated as:

$[\mathrm{Cd}]_{\text {sediment }}=$

$\left\{\mathrm{Cd}_{\text {total }}-\left(\mathrm{Cd}_{\text {porewater }}+\mathrm{Cd}_{\text {ovl. water }}\right)\right\} /(\mathrm{g}$ dry wt sed.added $)$

where $\mathrm{Cd}_{\text {total }}=$ the total amount of cadmium added ( $\mu \mathrm{g}$ Cd), $\mathrm{Cd}_{\text {porewater }}$ and $\mathrm{Cd}_{\mathrm{ovl} \text {. water }}=$ measured amounts of cadmium ( $\mathrm{gg} \mathrm{Cd}$ ) in the porewater and overlying water, respectively, and g dry wt sed.added $=$ dry weight of sediment.

Experimental set-up. Experiments were performed at $22^{\circ} \mathrm{C}\left( \pm 2^{\circ} \mathrm{C}\right)$, and worms were acclimated in the laboratory for $1 \mathrm{~d}$ prior to the experiments. WO worms were starved individually in $20 \mathrm{ml}$ vials (diam. = $2.5 \mathrm{~cm}$ ) containing $10 \mathrm{ml}$ of filtered (<0.2 $\mathrm{\mu m}$ ) seawater (31\%, $\mathrm{pH}$ : ca 6.8). Worms in PWS and SBO were grown individually in either $20 \mathrm{ml}$ vials (PWS, diam. $=2 \mathrm{~cm}$ ) containing $10 \mathrm{ml}$ of filtered seawater and $3 \mathrm{ml}$ of wet sediment (i.e. $3.12 \mathrm{~g}$ dry wt sed.) or in $20 \mathrm{ml}$ petri dishes (SBO, diam. $=5 \mathrm{~cm}$ ) to which were added $5 \mathrm{ml}$ filtered (GFC, $0.45 \mu \mathrm{m}$ ) seawater and $5 \mathrm{ml}$ wet sediment (ca $5.2 \mathrm{~g}$ dry wt sed). The vials were covered with plastic lids (each with a small hole) and the petri dishes with parafilm to minimize water evaporation during the experiments. The overlying water (WO, PWS: ca $9 \mathrm{ml}$; SBO: ca $3.5 \mathrm{ml}$ ) was renewed with aerated seawater at the same cadmium concentration $2 \mathrm{~h}$ before the start of an experiment and thereafter daily during all experiments. A summary of experiments, treatments, number of worms and measurements is provided in Table 2 . 
Table 2. Relations among experiments, treatments and measurements taken. Cadmium concentrations ( $\mu \mathrm{Cd} \mathrm{l}^{-1}$ seawater) refer to the nominal dissolved concentration in WO and SBO (before addition of sediment) and the porewater concentration in PWS (see text for further explanation). n: total number of worms. $(+)$ indicates that the measurement was made

\begin{tabular}{|c|c|c|c|c|c|c|c|c|c|c|}
\hline \multirow[t]{2}{*}{ Experiment } & \multicolumn{3}{|c|}{ Wo } & \multicolumn{3}{|c|}{ SBO } & \multicolumn{3}{|c|}{ PWS } & \multirow{2}{*}{$\mathrm{N}$} \\
\hline & 0 & 25 & 50 & 0 & 25 & 50 & 0 & & 50 & \\
\hline \multicolumn{11}{|l|}{ Growth experiment } \\
\hline Growth rate & + & + & + & + & + & + & + & + & + & $75^{\mathrm{d}}$ \\
\hline Egestion rate & & & & & & & + & + & + & 30 \\
\hline Uptake and depuration experimer & & & + & & & & & & + & 30 \\
\hline \multicolumn{11}{|l|}{ Additional measurements } \\
\hline Overlying water $[\mathrm{Cd}]$ & & + & + & & & & & & + & \\
\hline Porewater $[\mathrm{Cd}]$ & & & & & & & & & + & \\
\hline
\end{tabular}

Sampling and analysis of overlying water and porewater. Radioactive cadmium was used as a tracer to determine the concentration of cadmium in the overlying water and porewater. It was assumed that radioactive cadmium behaved identically to non-radioactive cadmium. Thus, the concentration of cadmium was calculated from the ratio of radioactive and nonradioactive cadmium.

The concentrations of dissolved cadmium in the overlying water $\left(\mathrm{WO}_{25,50}, \mathrm{PWS}_{25,50}\right)$ and in the porewater $\left(\mathrm{PWS}_{25,50}\right)$ were measured to test whether the concentration changed during the experiments $(5 \mathrm{~d})$. Before the start of an experiment, overlying water was sampled $(100 \mu \mathrm{l})$ from 4 different vials in WO and PWS prior to addition of sediment and gamma-counted. Hereafter. samples from the overlying water in WO and PWS were counted daily during the experiment. Porewater concentration of dissolved cadmium was measured in PWS treatments on Day $0(n=12)$ and Day $5(n=4)$ according to the following procedures. Overlying water (ca $10 \mathrm{ml}$ ) and wet sediment from each vial were transferred separately into 2 glass centrifuge tubes and centrifuged $(16 \mathrm{~min}$ at $3180 \times g)$. Subsequently, the supernatant from the sediment tube (i.e. the porewater) was transferred to a new tube and was recentrifuged to remove particles that were resuspended during the transfer. The supernatants from the centrifuged overlying water and the recentrifuged porewater were decanted to new tubes. The tubes were shaken and triplicate samples from each tube were gamma-counted.

Growth. The effects of dissolved $\left(\mathrm{WO}_{0}, 25,50\right)$, sedimentbound $\left(\mathrm{SBO}_{0,25,50}\right)$, and both dissolved and sedimentbound $\left(\mathrm{PWS}_{0,25,50}\right)$ cadmium on worm growth were investigated. There were 5 replicate worms in each cadmium treatment in SBO and 10 each in WO and PWS. Worms (WO, PWS and SBO) and pellets produced during $5 \mathrm{~d}$ in PWS treatments were gently removed from each vial or petri dish at the conclusion of the growth experiment. Worms were used for measurements of growth rate and worm allometry, and pellets were used for determination of egestion rate

Growth rate and allometry: Individual worm surface area $(A)$ and length $(L)$ were measured, and worm body volumes (BV, $\mathrm{mm}^{3}$ ) were estimated regularly during an $8 \mathrm{~d}$ period in a preliminary study. The results showed that individual BV was exponentially related to time such that $B V=$ $k_{1} \mathrm{e}^{|R t|}$, where $k_{1}=$ constant, $R=$ individual growth rate $\left(\mathrm{d}^{-1}\right)$ and $t=$ time in days. The relation between $A\left(\mathrm{~mm}^{2}\right)$ and $L$ ( $\mathrm{mm}$ ) was described by the power function: $\log (A)=$ $\log \left(k_{2}\right)+a \log (L)$, where $k_{2}=$ constant and $a$ $=$ allometric exponent (the slope on a log$\log$ scale). Growth rates and worm allometry were described by the same type of function for all cadmium exposures, in systems both with and without sediment. To avoid stressing the worms by frequently removing them from the sediment, individual worm BV was only estımated at the beginning $(t=0)$ and at the end $(t=5)$ of the experiment in PWS and WO. However, BV was measured 5 times in SBO during the experiment ( $9 \mathrm{~d}$ ). Growth rates were determined as changes in individual BV with time. The relation between individual worm surface area and length was used to test the effect of cadmium on worm allometry in WO, SBO and PWS treatments.

A video camera mounted on a dissection microscope was used to record live worms. Individual BVs were estimated from measurements of projected $A$ and $L$ assuming that worms are cylindrical in shape (Self \& Jumars 1978): $B V=\left[\left(\pi \times A^{2}\right) /(4 \times L)\right]$. Area and length were estimated using JAVA software (Jandel, Germany). Each worm-size estimate used in the analysis was the mean of 3 replicate volume determinations ( $\mathrm{SD}<10 \%$ ).

Egestion rate: Individual egestion rates were determined for worms in PWS treatments (same 30 worms for which growth rates were measured). Pellets were sieved $(125 \mu \mathrm{m})$ from each vial, cleaned in seawater and placed in a tube containing $75 \%$ EtOH until analysis. Pellets were cleaned in distilled water and transferred to a small tube prior to disaggregation by ultrasound (ca 1 h). Each tube was shaken (6 to 8 times) during this period to promote disaggregation of pellets. Disaggregated pellets were passed through a $63 \mu \mathrm{m}$ filter to separate dissolved pellets from large mineral grains that had been trapped on the $125 \mu \mathrm{m}$ sieve. dried $\left(24 \mathrm{~h}\right.$ at $105^{\circ} \mathrm{C}$ ) and weighed. Body-size-specific egestion rates were calculated as dry weight of pellets produced over $5 \mathrm{~d}$ divided by BV on Day $5\left(\mathrm{BV}_{\text {end }}\right)$

Uptake and depuration. This experiment was designed to investigate the kinetics of cadmium uptake 
and depuration in Capitella sp. I exposed to cadmium in the dissolved form $\left(\mathrm{WO}_{50} ; \mathrm{n}=15\right)$ or from both sediment and porewater $\left(\mathrm{PWS}_{50} ; \mathrm{n}=15\right.$ ) (Table 2). At the end of each exposure interval (i.e. at 1, 3 and $6 \mathrm{~h}$, and thereafter daily), individual worms were removed from their vials, cleaned in seawater $(<0.2 \mu \mathrm{m})$, gammacounted and placed in fresh, clean seawater $\left(\mathrm{WO}_{50}\right)$ and natural sediment $\left(\mathrm{PWS}_{50}\right.$ ) for $1 \mathrm{~h}$ to purge their guts. Subsequently, the worms were recounted and transferred to new vials containing contaminated sediment and/or water. Worms measured after 1 and $3 \mathrm{~h}$ exposure were not used again. Thus, 5 worms in each treatment were used during the remaining period. Following an uptake period of $5 \mathrm{~d}$, the worms were allowed to depurate in unlabeled filtered seawater $\left(\mathrm{WO}_{50}\right)$ and sediment $\left(\mathrm{PWS}_{50}\right)$ for $6 \mathrm{~d}$. During the depuration period, worms were sieved from their containers, removed from their tubes, rinsed in seawater, gamma counted and subsequently placed in new uncontaminated vials on a daily basis.

Cadmium body burdens in individual Capitella sp. I were assessed as total body burdens (TBB, i.e. total [Cd] worm ${ }^{-1}$ ) and as weight-specific body burdens (BB, i.e. total [Cd] $g^{-1}$ dry wt worm) (see below). Individual growth rates were determined from BV measured at the beginning and end of the uptake and depuration period. For every day of the uptake and depuration period, BV was estimated by linear interpolation from the estimated overall growth rate. BV was converted to dry weight according to Forbes \& Lopez (1987): DW = $150.9 \mathrm{BV}+2.08$, where $\mathrm{DW}=$ worm dry weight $(\mu \mathrm{g})$ and $\mathrm{BV}=$ body volume $\left(\mathrm{mm}^{3}\right)$. Net uptake rate $\left(k_{\mathrm{u}}\right)$, depuration rate $\left(k_{\mathrm{d}}\right)$ and half-life ( $T_{1 / 2}$, i.e. time to $50 \%$ reduction in $\mathrm{TBB}$ or $\mathrm{BB}$ ) were calculated as described by Spacie \& Hamelink (1985). The relation between $T_{1 / 2}$ and $k_{\mathrm{d}}$ is given by: $T_{1 / 2}=\ln 2 / k_{\mathrm{d}}$. The concentration factors (CF) were calculated as: $C F_{W_{O}}=\left[\mathrm{BB}_{5} /\left(\mu \mathrm{g} \mathrm{Cd} \mathrm{g}^{-1}\right)\right]$, and $\mathrm{CF}_{\mathrm{PWS}}=\mathrm{BB}_{5} / Q_{\text {, where }} \mathrm{BB}_{5}=\mu \mathrm{g} \mathrm{Cd} \mathrm{g}^{-1}$ dry wt worm on Day 5. BB was either related to the porewater concentration alone, in which case $Q=\mu \mathrm{g} \mathrm{Cd} \mathrm{g}{ }^{-1}$; to the sediment-bound pool of cadmium alone, in which

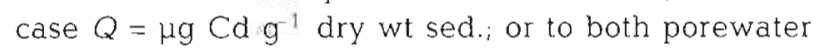
and sediment-bound cadmium, in which case $Q=\mu \mathrm{g}$

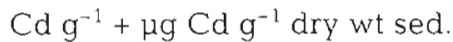

Statistical analysis. Analysis of data included 1-way ANOVA to test the significance of cadmium effects (significance level: $\mathrm{p}<0.05$ ). Tukey's HSD test was used to test for significant differences in pairwise comparisons among concentrations within treatments. Bartlett's test was used to test the homogeneity of variances among cadmium concentrations within treatments. Student's t-tests were performed when only 2 groups were involved. ANCOVA was used to test for significant $\mathrm{Cd}$ effects on the relation between worm area and length.

\section{RESULTS}

\section{Analysis of overlying water and porewater}

The dissolved cadmium concentration in wO remained constant at $99.3 \%( \pm 1.7)$ of the initial $(t=0)$ cadmium concentration (ANOVA; $\mathrm{p}=0.641$ ) throughout the course of the experiment $\left(\mathrm{WO}_{25}: 24.7 \pm 0.4\right.$, $\mathrm{WO}_{50}: 49.5 \pm 0.8 \mu \mathrm{g} \mathrm{Cd} \mathrm{l}^{-1}$ ). The cadmium content in the overlying water in PWS declined significantly (Tukey; $\mathrm{p}<<0.001)$ from Day $0(8.71 \pm 1.2 \%)$ to Day $1(3.23 \pm$ $1.9 \%)$, and thereafter remained constant at 2.36 $( \pm 1.3) \%$ of the initial concentration (ANOVA $;$ $0.355)$. This corresponds to overlying water concentrations of $96.8( \pm 53.3) \mu \mathrm{g} \mathrm{Cd} \mathrm{l^{-1 }}$ in $\mathrm{PWS}_{25}$ and 193.5 $( \pm 106.6) \mu \mathrm{g} \mathrm{Cd} \mathrm{l}{ }^{-1}$ in $\mathrm{PWS}_{50}$.

The porewater concentration of dissolved cadmium did not differ significantly between the beginning ( $t=$ $0)$ and the end $(t=5)$ of the experiment in PWS treatments (Table 3 ). The porewater concentrations of cadmium in PWS were on average 3.6 times lower than in the overlying water.

Table 3. Comparisons (Student's $t$-test) of measured porewater cadmium concentrations [mean $\pm 1 \mathrm{SD}$ (number of measurements)] on Day 0 and Day 5 of the experiment. $\mathrm{PWS}_{25}$ and $\mathrm{PWS}_{50}$ refer to the nominal porewater concentrations of cadmium in the porewater \& sediment treatment

\begin{tabular}{|lcc|}
\hline & $\mathrm{PWS}_{25}$ & $\begin{array}{c}\text { PWS }_{50} \\
\left(\mu \mathrm{g} \mathrm{Cd}^{-1}\right)\end{array}$ \\
\hline$t=0$ & $26.7 \pm 2.9(12)$ & $48.3 \pm 11.2(12)$ \\
$t=5$ & $26.6 \pm 2.2(4)$ & $52.5 \pm 5.0(4)$ \\
Probability & 0.918 & 0.489 \\
\hline
\end{tabular}

\section{Effect of cadmium on growth rate, egestion rate and worm allometry}

Worms in WO treatments had negative growth rates (degrowth rates) due to the absence of food (Fig. 1A). Cadmium had a significant negative effect on the degrowth rate in Capitella sp. I (ANOVA; $\mathrm{p}=0.009$ ). The degrowth rates were $-5( \pm 2.3) \% \mathrm{~d}^{-1}$ for controls $(0$ $\left.\mu \mathrm{g} \mathrm{Cd} \mathrm{l^{-1 }}\right),-7.3( \pm 2.8) \% \mathrm{~d}^{-1}$ at $25 \mu \mathrm{g} \mathrm{Cd} \mathrm{l}^{-1}$ and $-9.7 \%$ $\mathrm{d}^{-1}( \pm 3.1)$ at $50 \mu \mathrm{g} \mathrm{Cd}{ }^{-1}$ seawater. Degrowth rates did not differ significantly between controls $\left(\mathrm{WO}_{0}\right)$ and worms exposed to a dissolved cadmium concentration of $25 \mu \mathrm{g} \mathrm{Cd} \mathrm{l}^{-1}$ (Tukey, $\mathrm{p}=0.211$ ) or between worms exposed to 25 and $50 \mu \mathrm{g} \mathrm{Cd}^{-1}$ (Tukey, $\mathrm{p}=0.181$ ).

There was no significant effect of cadmium on growth rate in Capitella sp. I exposed to sedimentbound cadmium (SBO: ANOVA, $p=0.552$ ) or exposed to cadmium from both porewater and sediment (PWS: ANOVA, $p=0.151$ ) (Fig. $1 \mathrm{~B}, \mathrm{C}$ ). Worms maintained 

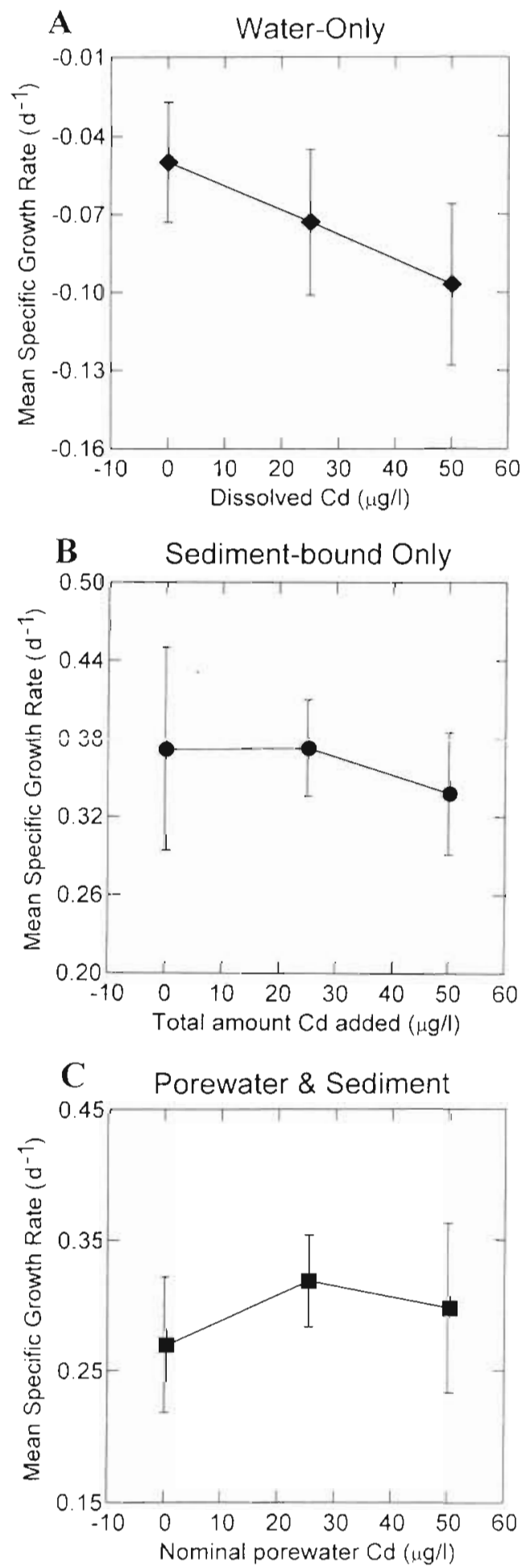

Fig. 1. Capitella sp. I. Individual volume-specific growth rates (mean $\pm \mathrm{SD}$ ) versus (A) dissolved nominal cadmium concentration in WO treatments ( $\mathrm{n}=10$ ), (B) the initial nominal dissolved cadmium concentration in SBO treatments $(n=5)$ before addition of sediment and $(\mathrm{C})$ nominal dissolved porewater concentration in PWS treatments $(n=10)$. Relation between growth rate $(R)$ and dissolved cadmium ([Cd $\left.\}_{\text {total }}\right)$ in WO treatments followed: $R=-0.001[\mathrm{Cd}]_{\text {cotal }}-0.05(\mathrm{r}=0.578, \mathrm{p}=0.002)$

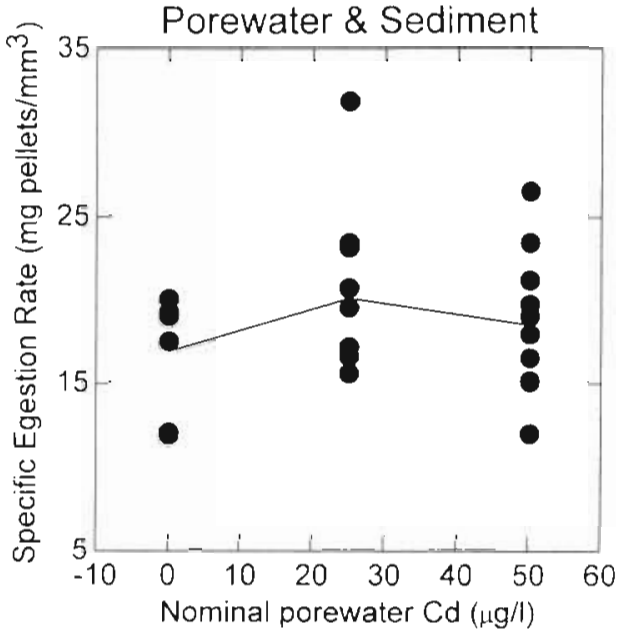

Fig. 2. Capitella sp. I. Relation between individual volumespecific egestion rate and the nominal porewater concentration of dissolved cadmium in PWS treatments

very high growth rates in both of these treatments regardless of cadmium exposure, with an average of $36 . i$ i 5.5 ) and $29.5( \pm 5.5) \% \mathrm{~d}^{-1}$, iespectively.

The volume-specific egestion rate of Capitella sp. I was not affected by cadmium exposure (ANOVA; $\mathrm{p}=$ 0.198 ) in PWS treatments. Capitella produced an average of $18.8( \pm 4.6) \mathrm{mg}$ pellets $\mathrm{BV}_{\text {end }}^{-1}$ during $5 \mathrm{~d}$ (Fig. 2).

The allometric exponent (i.e. slope) was independent of cadmium exposure within all 3 treatments (ANCOVA: WO, $\mathrm{p}=0.134 ; \mathrm{SBO}, \mathrm{p}=0.099 ;$ PWS, $\mathrm{p}=$ 0.234 ) (Table 4). Intercepts did not differ significantly among cadmium groups within WO and PWS (ANCOVA: $p=0.465$ and $p=0.177$, respectively), but did within SBO (ANCOVA: $p=0.008$ ). Comparison of the $95 \%$ confidence limits for the intercepts within $\mathrm{SBO}$ treatments showed that the intercept in $\mathrm{SBO}_{25}$ differed from $\mathrm{SBO}_{0} . \mathrm{SBO}_{25}$ and $\mathrm{SBO}_{50}$ overlapped, as did $\mathrm{SBO}_{0}$ and $\mathrm{SBO}_{50}$. Data were pooled within treatments, and the effect of treatment on allometry was determined by ANCOVA (Table 5). The slopes were significantly different among the 3 treatments (ANCOVA: p $<0.001)$. The confidence limits for the allometric exponent $(a)$ and the $y$-intercept $\left(\log k_{2}\right)$ did not overlap among the 3 treatments (Table 5).

\section{Analysis of cadmium uptake and depuration}

Total radioactivity in purged (for $1 \mathrm{~h}$ ) versus nonpurged Capitella sp. I did not differ significantly ( $\mathrm{p}>$ $0.05)$, and the data presented below are for purged worms. Worms in $\mathrm{WO}_{50}$ decreased their $\mathrm{BV}$ by $12.5 \%$ $\mathrm{d}^{-1}$, and worms in $\mathrm{PWS}_{50}$ increased their BV by $15.9 \%$ $\mathrm{d}^{-1}$ during the entire $11 \mathrm{~d}$ period (Fig. 3 ). 
Table 4. Statistics for the relation between worm area $(A)$ and length $(L)$ in the different cadmium concentrations within treatments: $\log (A)=a \log (L)+\log \left(k_{2}\right)$, where $\log \left(k_{2}\right)$ is the $y$-intercept of the regression and $a$ is the slope (i.e. allometric exponent) $n$ : number of measurements $(A, L) ; \mathrm{r}$ : correlation coefficient

\begin{tabular}{|c|c|c|c|c|c|c|c|c|}
\hline \multirow[t]{2}{*}{ Treatment } & \multirow[t]{2}{*}{ Mean a } & \multicolumn{2}{|c|}{ Confidence limits $(95 \%)$} & \multirow[t]{2}{*}{ Mean $\log \left(k_{2}\right)$} & \multicolumn{2}{|c|}{ Confidence limits $(95 \%)$} & \multirow[t]{2}{*}{$\mathrm{r}$} & \multirow[t]{2}{*}{$\mathrm{n}$} \\
\hline & & Lower & Upper & & Lower & Upper & & \\
\hline $\mathrm{WO}_{0}$ & 1.049 & 0.891 & 1.207 & -0.332 & -0.439 & -0.225 & 0.996 & 57 \\
\hline $\mathrm{WO}_{25}$ & 0.901 & 0.701 & 1.100 & -0.238 & -0.372 & -0.103 & 0.993 & 57 \\
\hline $\mathrm{WO}_{50}$ & 1.152 & 0.964 & 1.340 & -0.411 & -0.539 & -0.284 & 0.994 & 45 \\
\hline $\mathrm{SBO}_{0}$ & 1.785 & 1.738 & 1.832 & -0.777 & -0.803 & -0.743 & 0.991 & 138 \\
\hline $\mathrm{SBO}_{25}$ & 1.869 & 1.820 & 1.917 & -0.847 & -0.879 & -0.816 & 0.992 & 134 \\
\hline $\mathrm{SBO}_{50}$ & 1.828 & 1.758 & 1.897 & -0.820 & -0.864 & -0.766 & 0.984 & 137 \\
\hline $\mathrm{PWS}_{0}$ & 1.525 & 1.394 & 1.657 & -0.637 & -0.749 & -0.526 & 0.995 & 61 \\
\hline $\mathrm{PWS}_{25}$ & 1.607 & 1.516 & 1.697 & -0.688 & -0.764 & -0.613 & 0.997 & 60 \\
\hline $\mathrm{PWS}_{50}$ & 1.661 & 1.564 & 1.758 & -0.733 & -0.816 & -0.650 & 0.997 & 57 \\
\hline
\end{tabular}

Table 5. Statistics for the relation between worm area $(A)$ and length $(L)$ within treatments fi.e. data are pooled among $C d$ concentrations): $\log (A)=a \log (L)+\log \left(k_{2}\right)$, where $\log \left(k_{2}\right)$ is the $y$-intercept of the regression and $a$ is the slope (1.e. allometric exponent). $n$ : number of measurements $(A, L)$; r: correlation coefficient

\begin{tabular}{|c|c|c|c|c|c|c|c|c|}
\hline Treatment & Mean a & $\begin{array}{c}\text { Confidenc } \\
\text { Lower }\end{array}$ & $\begin{array}{l}\operatorname{limits}(95 \%) \\
\text { Upper }\end{array}$ & Mean $\log \left(k_{2}\right)$ & $\begin{array}{c}\text { Confidence } \\
\text { Lower }\end{array}$ & $\begin{array}{l}\text { limits }(95 \%) \\
\text { Upper }\end{array}$ & $\mathrm{r}$ & $\mathrm{n}$ \\
\hline WO & 1.038 & 0.933 & 1.142 & -0.330 & -0.402 & -0.259 & 0.994 & 154 \\
\hline $\mathrm{SBO}$ & 1.822 & 1.790 & 1.854 & -0.810 & -0.831 & -0.789 & 0.989 & 409 \\
\hline PWS & 1.598 & 1.536 & 1.659 & -0.686 & -0.738 & -0.635 & 0.996 & 176 \\
\hline
\end{tabular}

Fig. 3. Capitella sp. I. Relations between estimated worm body volume (mean $\pm \mathrm{SD}, \mathrm{n}=4$ ) and time. Exposure period: Days 0 to 5 ; depuration period: Days 5 to 11 (A) $W_{50}$ : mean growth rate $=-12.5 \% \mathrm{~d}^{-1} ; 95 \%$ confidence limits, lower $=-15.8 \%$ and upper $=-9.2 \%$. (B) PWS $_{50}$ : mean growth rate $=15.9 \% \mathrm{~d}^{-1}$; $95 \%$ confidence limits, lower = $13.0 \%$ and upper $=18.9 \%$

\section{A}

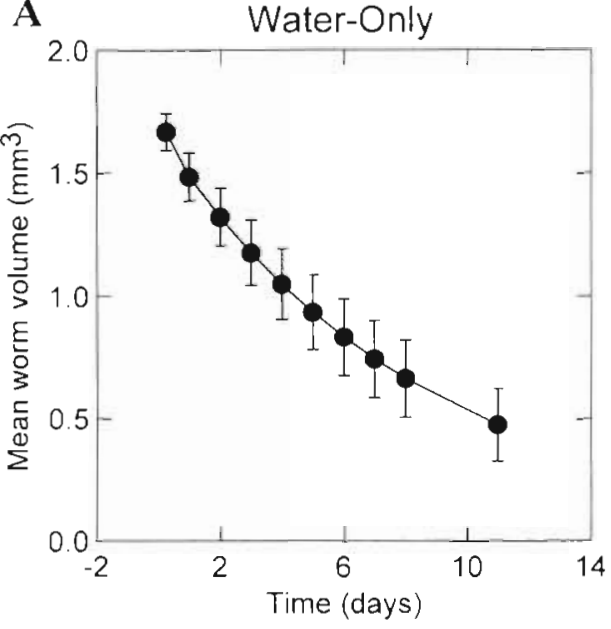

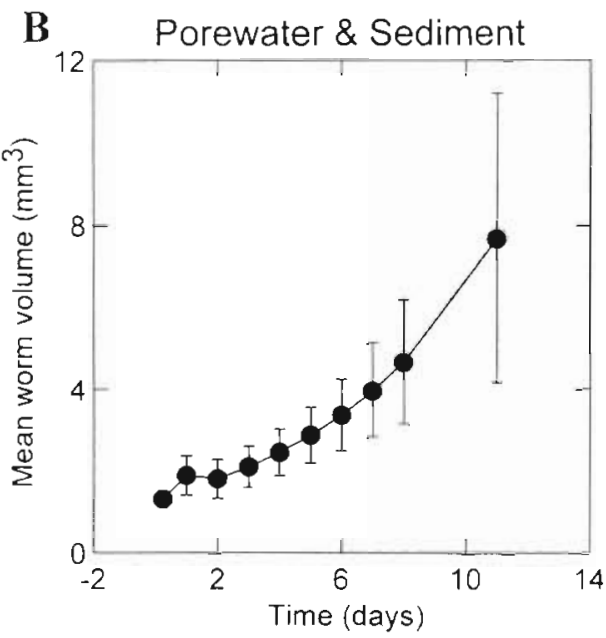

\section{Cadmium uptake}

The increases in $\mathrm{TBB}$ and $\mathrm{BB}$ of worms with exposure time were best described by power functions in both $W_{50}$ and PWS 50 treatments (Fig. 4). Accumulation of cadmium was considerably higher in $\mathrm{PWS}_{50}$ than in $\mathrm{WO}_{50}$. The total body burden of cadmium was ca 50 times higher in worms in $\mathrm{PWS}_{50}$ compared to worms in $\mathrm{WO}_{50}$ at the end of the uptake period, but only 17 times higher on a weight basis. These differences were reflected in $k_{\mathrm{u}}$ values that on average were ca 24 times higher in $\mathrm{PWS}_{50}$ (Table 6). The net $k_{u}$ declined as the weight-specific concentration of cadmium increased, indicating a trend toward a steady-state level, whereas TBB continued to increase as worms grew in PWS (Fig. 4). Worms in $\mathrm{WO}_{50}$ increased $\mathrm{TBB}$ and $\mathrm{BB}$ continuously, and no trend toward a steady state level was observed.

Comparison of cadmium concentration factors (CF) between $\mathrm{WO}_{50}$ and $\mathrm{PWS}_{50}$ depended on the pool of cadmium in PWS to which BB was related. CF was highest when related to the porewater alone and low- 


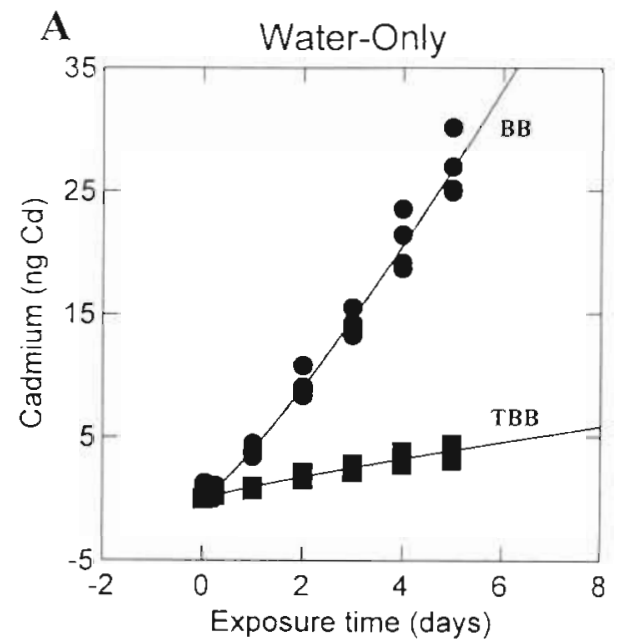

est when related to porewater and sediment (Table 7 ). Hence, CF for Capitella sp. I in PWS $\mathrm{PW}_{50}$ is ca 17 times higher than in $\mathrm{WO}_{50}$ if the porewater is considered as the sole route of uptake, but approximately 30 times lower if the sediment-bound pool of cadmium is aiso included as a route of uptake.

Table 6. Capitella sp. I. Net uptake rates $\left(k_{\mathrm{u}} \mu \mathrm{g} \mathrm{Cd} \mathrm{g}^{-1} \mathrm{dry}\right.$ wt worm ${ }^{-1} d^{-1}$ ) from the uptake period

\begin{tabular}{|lcc|}
\hline Hour & WO & PWS \\
\hline 1 & 23.86 & 281.5 \\
3 & -4.43 & 292.5 \\
6 & 3.26 & 165.7 \\
24 & 3.80 & 76.8 \\
48 & 5.35 & 137.2 \\
72 & 4.94 & 74.4 \\
96 & 6.59 & 71.4 \\
120 & 6.08 & 69.9 \\
Average $k_{\mathrm{u}}$ & 6.18 & 146.11 \\
\hline
\end{tabular}

Table 7. Capitella sp. I. Cadmium concentration factors (CF) for worms in $\mathrm{WO}_{50}$ and $\mathrm{PWS}_{50}$ treatments. $\mathrm{CF}=\mathrm{BB}_{5} / \mathrm{Q}_{\text {, whe }}$ $\mathrm{BB}_{5}$ is the volume-specific body burden at the end of the exposure period, and $Q$ is the [Cd] in (1) the dissolved pool $\left(0.05 \mu \mathrm{g} \mathrm{Cd} \mathrm{g}^{-1}\right),(2)$ the sediment bound pool $\left(25.7 \mu \mathrm{g} \mathrm{Cd} \mathrm{g}^{-1}\right)$, (3) in the dissolved plus sediment bound pool $(0.05+25.7 \mu \mathrm{g}$ $\mathrm{Cd}^{-1}$ ), and (4) the overlying water on Day 1 of the experiment (i.e. $0.194 \mu \mathrm{g} \mathrm{Cd} \mathrm{g}^{-1}$ )

\begin{tabular}{|llc|}
\hline \multirow{2}{*}{ Treatment } & Pool of cadmium & Concentration factor \\
\hline $\mathrm{WO}_{50}$ & Dissolved & 536.8 \\
PWS $_{50}$ & Only dissolved porewater & 9343.8 \\
& Only sediment-bound & 18.2 \\
& Porewater and sediment & 18.1 \\
& Only overlying water & 2420.7 \\
\hline
\end{tabular}

\section{Cadmium depuration}

In general, an exponential function provided the best fit to the change in BB and TBB with depuration time (Fig. 5), indicating inat depuration could diequaiely be described by a 1-compartment model. A possible exception was TBB in $\mathrm{PWS}_{50}$, which appears to show a slower loss rate after $2 \mathrm{~d}$ (Fig. 5B).

Worms in $\mathrm{WO}_{50}$ treatments did not decrease TBB significantly ( $A N O V A_{i} p=0.127$ ), and $T B B$ remained constant at $99.4 \%( \pm 2.2)$ during the depuration period. In contrast, BB increased significantly (ANOVA; $\mathrm{p} \ll$ $0.05)$ from $100 \%(t=0)$ to $195 \%( \pm 22.3 ; t=6)$ in $W_{50}$ worms (Fig. 5A).

Worms in $\mathrm{PWS}_{50}$ treatments decreased both $\mathrm{BB}$ and $\mathrm{TBB}$, though $\mathrm{BB}$ decreased at a faster rate (Fig. 5B). Hence, the weight-specific half-life $\left(T_{1 / 2}: 3.0 \mathrm{~d}\right)$ was approximately 3.5 times shorter than the half-life of the total body burden ( $T_{1 / 2}: 10.7 \mathrm{~d}$ ). Furthermore, growing worms $\left(\mathrm{PWS}_{50}\right.$ ) were able to halve the total body burden of cadmium ca 16 times faster than starving worms $\left(\mathrm{WO}_{50}: T_{1 / 2}=173.3 \mathrm{~d}\right)$.

\section{DISCUSSION}

\section{Effect of cadmium on growth rate, egestion rate and worm allometry}

Cadmium significantly increased the shrinkage rate of Capitella sp. I in water-only treatments (from -5 to $-9.7 \% \mathrm{~d}^{-1}$ ). However, there was no negative effect of cadmium on growth in sediment-bound only and porewater \& sediment treatments, despite the fact that the dissolved cadmium concentration in WO was equal to the concentration in the porewater and lower than the concentration in the overlying water in PWS. This dif- 
Fig. 5. Capitella sp. I. Relations between $\mathrm{BB}, \mathrm{TBB}$ and depuration time for individual worms $(n=4)$ in the (A) WO treatment and $(\mathrm{B})$ PWS treatment. Abbreviations as in Fig. 4. Lines are locally weighted scatterplot smooths. Exponential functions: $\mathrm{WO}_{50}, \mathrm{TBB}$ $=100 \mathrm{e}^{-0.004 \text { day }}(\mathrm{r}=1.00), \mathrm{BB}=$ $100 e^{0.111 \text { day }}(r=0.997) ; \mathrm{PWS}_{50}$ $\mathrm{TBB}=100 \mathrm{e}^{-0.065 \text { day }}(\mathrm{r}=0.998)$, $\mathrm{BB}=100 \mathrm{e}^{-0.228 \mathrm{day}}(\mathrm{r}=0.994)$
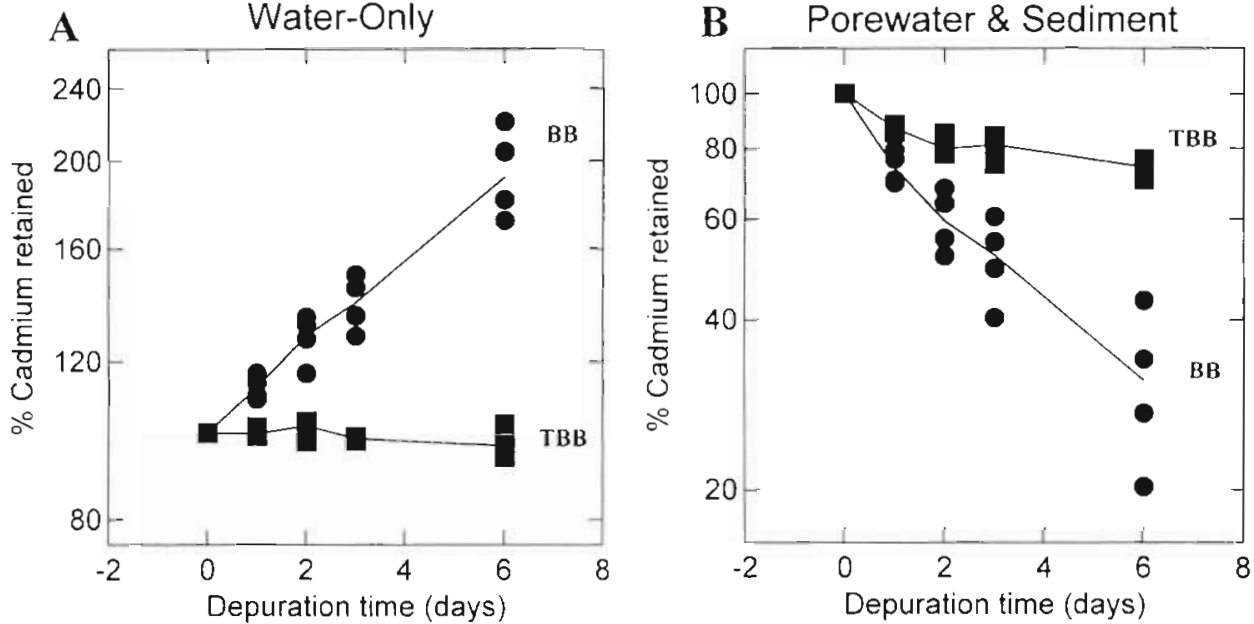

ference in effect may be related to differences in energy intake (as well as route of Cd uptake) between worms in WO (= starved) and SBO/PWS (= fed) treatments. Organisms allocate the energy absorbed from food to both maintenance requirements and growth (Calow \& Sibly 1990). Dealing with chemical stress is likely to involve some degree of added energy expenditure, which can be obtained by increasing energy intake or by use of energy reserves otherwise used for growth and maintenance requirements (Calow \& Sibly 1990, Langston \& Spence 1995). There was no indication in the present experiments that worms responded to cadmium exposure by increasing energy intake, as egestion rates did not differ among cadmium concentrations in PWS treatments.

When food is limited, Capitella sp. I is able to use its own tissue as an energy source and can survive substantial reductions in its body volume (Eckelbarger et al. 1984, Forbes et al. 1994). Our results suggest that starving worms use their own tissue to maintain the metabolic process(es) required to deal with metal stress. Thus, we observed more rapid shrinkage rates of cadmium-exposed worms relative to unexposed worms in the absence of food.

The mean growth rates of worms in SBO and PWS were higher ( 30 and $36 \% \mathrm{~d}^{-1}$, respectively) than previously reported (up to $25 \% \mathrm{~d}^{-1}$; Tenore \& Chesney 1985 , Forbes \& Lopez 1987, Forbes \& Lopez 1990). The difference in average growth rate between SBO and PWS is not likely to be an effect of cadmium. Oxygen concentration may have been lower in PWS relative to SBO, because of a deeper water column and partitioning of the sediment into an oxic and anoxic phase in PWS. A decrease in oxygen level is known to reduce the growth of Capitella sp. I (Forbes \& Lopez 1990).

Cadmium had no effect on worm allometry within the 3 treatments, and there were no differences among the $y$-intercepts within WO and PWS treat- ments. It is not likely that the difference in intercepts among cadmium concentrations in the SBO treatment was a response to exposure, since the intercepts only differed between $\mathrm{SBO}_{0}$ and $\mathrm{SBO}_{25}$ and not between $\mathrm{SBO}_{0}$ and $\mathrm{SBO}_{50}$. Comparison of the allometric exponent and the intercepts among treatments (WO, SBO, PWS) for worms not exposed to cadmium indicated a significant difference (Table 5). Therefore, the data suggest that worm allometry is affected by feeding conditions. The relation between area and length was very close to being linearly proportional in starving worms (WO: $a=1.04$ ), whereas growing worms were relatively wider (SBO: $\alpha=1.82$; PWS: $a=1.60$ ). The allometry of the polychaete Streblospio benedicti is also dependent on feeding conditions; in contrast to Capitella sp. I they are relatively wider and shorter when starving, compared to thinner and longer during growth and regrowth (P. Huggins pers. comm.). The importance of changes in worm allometry is a subject that needs further consideration, and the growth dynamics of Capitella sp. I may be more complex than can be described by a single average allometric exponent (Forbes \& Lopez 1989).

\section{Cadinium uptake and depuration kinetics}

The estimated growth rate in Capitella sp. I was lower $\left(\mathrm{PWS}_{50}\right.$ : $\mathrm{Ca} 15.9 \% \mathrm{~d}^{-1}$ ) and the shrinkage rate faster $\left(\mathrm{WO}_{50}:-12.5 \% \mathrm{~d}^{-1}\right)$ in the uptake and depuration experiment compared to measured rates in the growth experiment (ca 30 and $-10 \% \mathrm{~d}^{-1}$, respectively). Worms in the uptake and depuration experiment were shifted among vials and gamma tubes several times daily and such disturbance likely acted as an additional source of stress and/or reduced feeding rates in this experiment.

Capitella sp. I has 3 possible uptake routes for cadmium in systems with sediment $\left(\mathrm{PWS}_{50}\right)$ : (1) from 
ingestion of sediment and subsequent accumulation over gut epithelium; (2) from porewater; and (3) from overlying water. The last 2 routes involve diffusion from water across the worm body surface, followed by accumulation over epidermal membranes. Epidermal membranes are possible uptake routes for worms in $\mathrm{WO}_{50}$ as well. The rate of cadmium uptake by Capitella sp. I depended on the presence of sediment, with starving worms ( $\mathrm{WO}_{50}$ ) having a much slower (ca 24 times) uptake rate than feeding worms $\left(\mathrm{PWS}_{50}\right)$. Also the total body burden and the weight-specific body burden were lower (ca 50 and 17 times, respectively) in $\mathrm{WO}_{50}$ compared to $\mathrm{PWS}_{50}$ at the end of the experiment. Worms in $\mathrm{WO}_{50}$ concentrated cadmium 537 -fold in $5 \mathrm{~d}$. The concentration factors in $\mathrm{PWS}_{50}$ depended on whether the amount of cadmium taken up was related to porewater cadmium alone (CF: ca 9344) or if the concentration of cadmium in the sediment was included (CF: ca 18).

Metal uptake is believed primarily to involve an initial interaction of the free metal ion with a transport system (i.e. channel or carrier) in the epithelium (external and/or internal), though uptake of other metal species, apart from free ions, can occur (e.g. Mason \& Jenkins 1995, Simkiss \& Taylor 1995, Simkiss 1996). The uptake of metal-ligand complexes is presumed to occur in response to a concentration gradient, such that cadmium goes from dissolved complexes to more stable sulfide groups in the cells (Mason \& Jenkins 1995). Most literature suggests that the free cadmium ion is the most bioavailable cadmium species in the aquatic environment (e.g. Blust et al. 1995, Dai et al. 1995). Assuming that the free cadmium ion is the most bioavailable fraction for uptake in Capitella sp. I and that the concentrations of dissolved cadmium ions were equal between WO and the porewater in PWS, we expected that worms in $W_{50}$ would accumulate at least as much cadmium as worms in $\mathrm{PWS}_{50}$. One possible explanation for the substantially higher body burdens in $\mathrm{PWS}_{50}$ compared to $\mathrm{WO}_{50}$ is that the cadmium dissolved in the porewater in $\mathrm{PWS}_{50}$ was in a more bioavailable form than the dissolved cadmium in $\mathrm{WO}_{50}$. However, complexation of metals with organic ligands and colloids dissolved in porewater results in a decrease in the concentration of free cadmium ions and is thought to result in reduced bioavailability of the metal to aquatic organisms (e.g Blust et al. 1995, Dai et al. 1995, Landrum et al. 1996). Therefore, even though the total concentration of dissolved cadmium was equal between WO and PWS, it is likely that a greater fraction of dissolved cadmium was present as free ions (and hence was more bioavailable) in WO than in PWS treatments (because of a higher concentration of organic ligands and colloids in sediment-containing treatments). Therefore, a greater bioavailabil- ity of porewater cadmium is not a likely explanation for the higher uptake in PWS compared to WO treatments.

A second possible explanation for the substantially higher body burdens in $\mathrm{PWS}_{50}$ compared to $\mathrm{WO}_{50}$ is that worms in PWS accumulated cadmium from the overlying water, the concentration of which was 4 times greater than the porewater concentration (Table 1). Although infauna are often viewed as being in intimate contact with sediment porewater, worms living in tubes may actually be in closer contact with cadmium dissolved in overlying water than in porewater because (1) the tube creates a barrier for cadmium in the porewater, reducing direct contact between worms and porewater, and (2) worms exchange the water in their tubes with overlying water during irrigation (Aller 1982, Cammen 1987, Landrum et al. 1996). If we assume that worms mainly took up cadmium from the overlying water in $\mathrm{PWS}_{50}$, this gives a concentration factor of 2421 (which is still 4.5 times higher than in $W_{50}$ ). Likewise, if we include both porewater and overlying water as routes of cadmium uptake, the concentration factor in $\mathrm{PWS}_{50}$ is still 3.58 times higher than in $\mathrm{WO}_{50}$.

A third possible explanation for the substantially higher body burdens in $\mathrm{PWS}_{50}$ compared to $\mathrm{WO}_{50}$ is that Capitella sp. I in $\mathrm{PWS}_{50}$ were able to absorb sediment-associated cadmium. Deposit feeders, such as Capitella sp. I, select and ingest large amounts of fine sediment particles that tend to be enriched in organic material, and hence metals. Thus worms can be exposed to a very high concentration of cadmium from ingested sediment (Campbell \& Tessier 1996). Absorption of cadmium across the gut will involve alteration of the ingested particulates to a dissolved form, followed by a facilitated diffusion across the intestinal epithelium (Luoma 1983). Metal absorption is dependent on food type, gut retention time and $\mathrm{pH}$ (Luoma 1983). Uptake of cadmium by mice is $\mathrm{pH}$ dependent, as cadmium is taken up over the epithelium cells at $\mathrm{pH}$ values between 1 and 4 , but hardly at all at higher pH (Sørensen et al. 1993). Cadmium is present as free cadmium ions at low $\mathrm{pH}$, which are easily absorbed, whereas high $\mathrm{pH}$ promotes complexation of cadmium with various food components and subsequently decreases absorption (Sørensen et al. 1993). The digestive $\mathrm{pH}$ of most deposit-feeding organisms ranges between 6 and 7 (Luoma 1983, Frithsen 1984), suggesting that $\mathrm{H}^{+}$is not likely responsible for solubilization of sedimentary metals. Alternatively, gut amino acids appear to play a major role in the release of metals from ingested sediments (Chen \& Mayer 1998)

Following Langston \& Spence (1995) we can estimate the contribution of sediment-bound cadmium to the total cadmium body burden by comparing the weight-specific body burdens of cadmium in starved 
and fed animals. By relating the weight-specific body burden for worms in $\mathrm{WO}_{50}\left(\mathrm{BB}_{\text {wo }}\right)$ with body burden for worms in $\mathrm{PWS}_{50}\left(\mathrm{BB}_{\mathrm{PW}}\right.$ ), we estimate that $95 \%$ of the cadmium taken up by Capitella sp. I in $\mathrm{PWS}_{50}$ was from the sediment-bound pool. The concentration factor for uptake from the sediment-bound pool was ca 17 as calculated by relating the 'corrected' concentration of cadmium ( $\left.\mathrm{BB}_{\mathrm{P} w \mathrm{~S}}-\mathrm{BB}_{\text {wo }}\right)$ taken up during the exposure period ( $440.35 \mu \mathrm{g} \mathrm{Cd} \mathrm{g}{ }^{-1}$ dry wt worm) to the concentration of cadmium in the sediment $\left(25.7 \mu \mathrm{g} \mathrm{Cd}^{-1}\right.$ dry wt sediment).

Starving worms did not reduce their total body burden of cadmium significantly ( $T_{1 / 2}: 173 \mathrm{~d}$ ), but increased their weight-specific body burden during the depuration period. Since excretion of cadmium was essentially zero, the increase in the weight-specific body burden was a direct result of the shrinkage of starving worms. In contrast, feeding worms decreased both their total body burden and weight-specific body burden of cadmium during the depuration period. Because worms were actively growing, weight-specific body burdens decreased approximately 3.5 times faster than total body burdens. Thus, both active excretion of cadmium and dilution of cadmium body burden by incorporation of new tissue contributed to the cadmium content of feeding worms.

Differences in excretion between worms exposed to cadmium via water versus water and sediment suggest that cadmium taken up by epidermal cells is eliminated at a slower rate than cadmium taken up over the gut wall. In addition, worms exposed to $\mathrm{Cd}$ in water experienced a more pronounced reduction in body volume compared to worms exposed to $\mathrm{Cd}$ via ingested sediment, despite the much higher $\mathrm{Cd}$ body burdens attained by the latter group. Together, these results suggest that cadmium absorbed over the body wall enters the target sites more readily, is harder to depurate and is thereby more toxic than cadmium absorbed across the gut.

\section{CONCLUSIONS}

It is known that food limitation controls depositfeeder populations in nature. Although the present design included an extreme food situation, the results indicate that heavy metals may be especially important for population growth during periods of food scarcity when organisms seem to be physiologically more sensitive to heavy metal stress

Increasing concern that sediments may be important sources of contaminants in aquatic systems has led to efforts toward developing sediment-quality criteria, and in this regard the most common approaches for estimating sediment-quality criteria have involved the assumption that benthic organisms, like pelagic species, are exposed to primarily dissolved contaminants. Our results show that uptake from the sediment-bound fraction is the primary route of cadmium absorption for Capitella sp. I and therefore question the relevance of present approaches for assessing sediment-quality criteria for contaminants. Exclusive focus on the dissolved phase is likely to substantially underestimate the actual accumulation of contaminants by benthic deposit-feeding organisms. However, subsequent toxicity does not appear to be a simple function of contaminant body burden, and both the route(s) and rates of uptake need to be considered.

Acknowledgements. We are grateful to Flemming Thorbjorn Hansen, Sam Luoma, and 2 anonymous reviewers for critical comments on the manuscript, to Anne Grete Sørensen for laboratory assistance, and to Ole Andersen for providing ${ }^{109} \mathrm{Cd}$.

\section{LITERATURE CITED}

Aller RC (1982) The effects of macrobenthos on chemical properties of marine sediment and overlying water. In: McCall PL, Tevesz MJS (eds) Animal-sediment relations. Plenum, New York, p 53-102

Ankley GT, Thomas NA, DiToro DM, Hansen DJ, Mahony JD, Berry WJ, Swartz RC, Hoke RA, Garrison AW, Allen HE, Zarba CS (1994) Assessing potential bioavailability of metals in sediments: a proposed approach. Environ Manag 18:331-337

Baudo R, Muntau H (1990) Lesser known in-place pollutants and diffuse source problems. In: Baudo R, Giesy JP, Muntau $H$ (eds) Sediments: chemistry and toxicity of inplace pollutants. Lewis Publishers, Inc, Boca Raton, FL, p $1-14$

Blust R, Baillieul M, Decleir W (1995) Effect of total cadmium and organic complexing on the uptake of cadmium by the brine shrimp. Artemia franciscana. Mar Biol 123:65-73

Bryan GW (1984) Pollution due to heavy metals and their compounds. In: Kinne O (ed) Marine ecology, Vol 5, Part 3. John Wiley \& Sons Ltd, Chichester, p 1289-1431

Bryan GW, Hummerstone LG (1973) Adaptation of the polychaete Nereis diversicolor to estuarine sediments containing high concentrations of zinc and cadmium. J Mar Biol Assoc UK 53:839-857

Bryan GW, Uysal H (1978) Heavy metals in the burrowing bivalve Scrobicularia plana from the Tamar estuary in relation to environmental levels. J Mar Biol Assoc UK 58: 89-108

Calow P, Sibly RM (1990) Essay review. A physiological basis of population processes: ecotoxicological implications. Funct Ecol 4:283-288

Cammen LM (1987) Polychaeta. In: Pandian TJ, Vernberg FJ (eds) Animal energetics, Vol 1 Academic Press, Inc, San Diego, p 217-260

Campbell PGC. Tessier A (1996) Ecotoxicology of metals in the aquatic environment: geochemical aspects. In: Newman MC, Jagoe CH (eds) Ecotoxicology: a hierarchical treatment. Lewis Publishers, Inc, Boca Raton, FL, p 11-58

Chen Z, Mayer LM (1998) Digestive proteases of the lugworm (Arenicola marina) nhibited by $\mathrm{Cu}$ from contaminated sediments. Environ Toxicol Chem 17(3):433-438

Dai M, Martin JM, Cauwet $G$ (1995) The significant role of 
colloids in the transport and transformation of organic carbon and associated trace metals ( $\mathrm{Cd}, \mathrm{Cu}$ and $\mathrm{Ni}$.) in the Rhône delta (France). Mar Chem 54:159-175

Eckelbarger KJ, Linley PA, Grassle JP (1984) Role of ovarian. follicle cells in vitellogenesis and oocyte resorption in Capitella sp. I. Mar Biol 79:133-144

Forbes TL, Forbes VE, Depledge MH (1994) Individual physiological responses to environmental hypoxia and organic enrichment: implications for early soft-bottom community succession. J Mar Res 52:1080-1100

Forbes TL, Lopez GR (1987) The allometry of deposit feeding in Capitella species I (Polychaeta: Capitellidae): the role of temperature and pellet weight in the control of egestion. Biol Bull. (Woods Hole) 172:187-201

Forbes TL, Lopez GR (1989) Determination of critical periods in ontogenetic trajectories. Funct Ecol 3:625-632

Forbes TL, Lopez GR (1990) Ontogenetic changes in individual growth and egestion rates in the deposit-feeding polychaete Capitella sp. I. J Exp Mar Biol Ecol 143:209-220

Forbes VE (1991) Response of Hydrobia ventrosa (Montagu) to environmental. stress: effects of salinity fluctuations and cadmium exposure on growth. Funct Ecol 5:642-648

Forbes VE, Depledge MH (1992) Cadmium effects on the carbon and energy balance of mudsnails. Mar Biol 113: $263-269$

Forbes VE, Forbes TL (1994) Ecotoxicology in theory and practice. Chapman \& Hall, London

Frithsen JB (1984) Metal incorporation by benthic fauna: relationships to sediment inventory. Estuar Coast Shelf Sci 19: 523-539

Grassle JF, Grassle JP (1974) Opportunistic life histories and genetic systems in marine benthic polychaetes. J Mar Res 80:3032-3043

Grassle JF, Grassle JP (1976) Sibling species of the marine pollution indicator Capitella (Polychaeta). Science 192: $567-569$

Harvey RW, Luoma SN (1985a) Separations of solute and particulate vectors of heavy metal uptake in controlled suspension-feeding experiments with Macoma balthica. Hydrobiologia 121:97-102

Harvey RW, Luoma SN (1985b) Effect of adherent bacteria and bacterial extracellular polymers upon assimilation by Macoma balthica of sediment-bound Cd, $\mathrm{Zn}$ and Ag. Mar Ecol Prog Ser 22:281-289

Kemp PF, Swartz RC (1988) Acute toxicity of interstitial and particle-bound cadmium to a marine infaunal amphipod. Mar Environ Res 26:135-153

Landrum P. Harkey GA, Kukkonen J (1996) Evaluation of organic contaminant exposure in aquatic organisms; the significance of bioconcentration and bioaccumulation. In: Newman MC, Jagoe CH (eds) Ecotoxicology. A hierarchical treatment. Lewis Publishers, Inc, Boca Raton, FL, p 85-132

Langston WJ, Spence SK (1995) Biological factors involved in metal concentrations observed in aquatic organisms. In: Tessier A. Turner DR (eds) Metal speciation and bioavailability in aquatic systems. John. Wiley and Sons, New York, p 407-478

Luoma SN (1983) Bioavailability of trace metals to aquatic organisms - a review. Sci Total Environ 28:1-22

Editorial responsibility: John Gray (Contributing Editor), Oslo, Norway
Mason AZ, Jenkins KD (1995) Metal detoxification in aquatic organisms. In: Tessier A, Turner DR (eds) Metal speciation and bioavailability in aquatic systems. John Wiley and Sons. New York, p 479-608

Pearson TH, Rosenberg R (1978) Macrobenthic succession in relation to organic enrichment and pollution of the marine environment. Oceanogr Mar Biol Annu Rev 16:229-311

Power EA, Chapmann PM (1992) Assessing sediment quality. In: Burton AG Jr (ed) Sediment toxicity assessment. Lewis Publishers, Inc, Boca Raton, FL, p 1-18

Rasmussen E (1973) Systematics and ecology of the Isefjord marine fauna (Denmark) with a survey of the eelgrass (Zostera) vegetation and its communities. Ophelia II: $1-507$

Ray S, Mcleese D. Pezzack D (1980) Accumulation of cadmium by Nereis virens. Arch Environ Contam Toxicol 9 : $1-8$

Reynoldson TB (1987) Interactions between sediment contaminants and benthic organisms. Hydrobiologia 149:53-66

Rhoads DC (1974) Organism-sediment relations on the muddy sea floor. Oceanogr Mar Biol Annu Rev 12: $263-300$

Self RFL, Jumars PA (1978) New resource axes for deposit feeders? J Mar Res 36:627-641.

Simkiss K (1996) Ecotoxicants at the cell-membrane barrier. In: Newman MC, Jagoe $\mathrm{CH}$ (eds) Ecotoxicology: a hierarchical treatment. Lewis Publishers, Inc, Boca Raton, FL, p 59-84.

Simkiss K, Taylor MG (1995) Transport of metals across membranes. In: Tessier A, Turner DR (eds) Metal speciation and bioavailability in aquatic systems. John Wiley and Sons, New York, p 1-44

Sørensen JA, Nielsen JB, Andersen O (1993) Identification of the gastrointestinal absorption site for cadmium chloride in vivo. Pharmacol Toxicol 73:169-173

Spacie A, Hamelink JL (1985) Bioaccumulation. In: Rand GM, Petrocelli SR (eds) Fundamentals of aquatic toxicology. Hemisphere, New York, p 495-525

Tenore KR, Chesney EJ Jr (1985) The effects of interaction of rate of food supply and population density on the bioenergetics of the opportunistic polychaete, Capitella capitata (Type 1), Limnol Oceanogr 30(6):1188-1195

Theede $H$ (1980) Physiological responses of estuarine animals to cadmium pollution. Helgoländer Meeresunters 33: $26-35$

Tsutsumi H (1987) Population dynamics of Capitella capitata (Polychaeta: Capitellidae) in an organically polluted cove Mar Ecol Prog Ser 36:139-149

Tsutsumi H (1990) Population persistence of Capitella sp. (Polychaeta; Capitellidae) on a mud flat subject to environmental disturbance by organic enrichment. Mar Ecol Prog Ser 63:147-156

Tsutsumi H, Fukunaga S, Fujita N (1990) Relationship between growth of Capitella sp. and organic enrichment of the sediment. Mar Ecol Prog Ser 63:157-162

Tsutsumi $\mathrm{H}$, Kikuchi T, Tanaka M, Higashi $T$, Imasaka K, Miyasaki M (1991) Benthic succession in a cove organically polluted by fish farming. Mar Pollut Bull 23:233-238

Ueda T, Nakamura R, Suzuki Y (1976) Comparison of. ${ }^{115} \mathrm{Cd}$ accumulation from sediments and seawater by polychaete worms. Bull Jpn Soc Sci Fish 42(3):299-306

Submitted: July 12, 1997; Accepted: February 9, 1998

Proofs received from author(s): March 19, 1998 